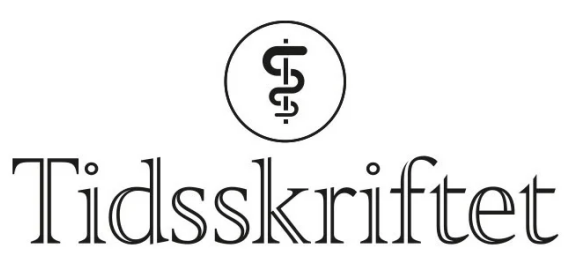

DEN NORSKE LEGEFORENING

\title{
Covid-19: Akkurat passe ulv
}

FRA REDAKTØREN

\section{RAGNHILD ØRSTAVIK}

ragnhild.orstavik@tidsskriftet.no

Ragnhild Ørstavik er assisterende sjefredaktør i Tidsskriftet. Hun er dr.med. og har en bistilling som forsker ved Folkehelseinstituttet.

\section{Helsemyndighetene skal informere om det nye koronaviruset uten å skape unødig engstelse. Men er det mulig?}

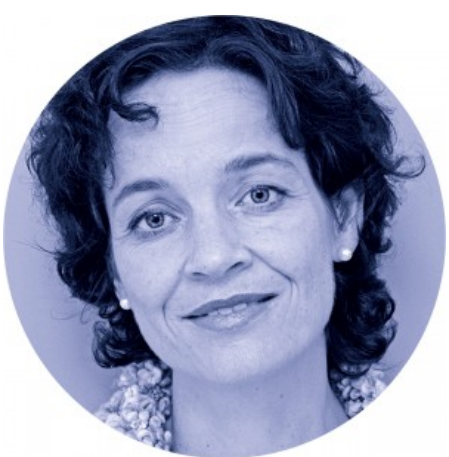

Foto: Einar Nilsen

I begynnelsen av januar 2015 stengte butikken Coming Attractions Bridal \& Formal i Ohio, etter 30 års drift (1). Noen måneder tidligere hadde sykepleieren Amber Vinson vært der for å se på brudekjoler, før hun reiste tilbake til Dallas og ble diagnostisert med ebola. Eieren av butikken stengte i to uker og steriliserte alle kjolene, til tross for at viruset kun smitter via kroppsvæsker fra syke pasienter. Kundene kom aldri tilbake til «ebola-butikken» (1).

Når en epidemi er i emning, skal helsemyndighetene være forberedt på det verste. Samtidig skal befolkningen få nøktern og oppdatert informasjon. Koronaviruset SARS-CoV-2 ser ut til å være ganske smittsomt, men gir relativt sjelden alvorlig sykdom (22). Foreløpig ser utbredelsen av sykdommen i Norge ut til å gjenspeile dette. Utviklingen er imidlertid svært usikker.

Oppdatert informasjon fra troverdige kilder regnes som ett av de viktigste tiltakene i startfasen av en epidemi (3). Men mens Folkehelseinstituttet informerer om smittevern og betydningen av hånd- og hostehygiene, hamstrer befolkningen vann (4). Vann står ganske riktig på listen over hva Direktoratet for samfunnssikkerhet og beredskap anbefaler at vi 
har et lite nødlager av hjemme, men det er ingen indikasjoner på at vi mister vannforsyningen med det første. På mitt lokale apotek er de utsolgt for Antibac og forteller om pasienter som får benzodiazepiner mot «korona-angst». Mange er rett og slett redde.

Det er ingen grunn til å le av butikkvegrende amerikanere eller undre seg over unødvendig hamstring. Sarsepidemien i 2003 hadde konsekvenser langt ut over de omkring 10 ooo som ble syke (5). Mye av dette skyldtes feilaktig og unødig skremmende informasjon, både fra myndigheter og ikke minst massemedia (5). Redsel er ikke nødvendigvis rasjonelt, og reaksjonen på en mulig fare ikke proporsjonal med risikoen for at det faktisk skjer (므). Tvert imot ser det ut til at vi er mer opptatt av muligheten til å beskytte oss enn av sannsynligheten for hendelsen (므). Hjernen tenderer til å overdrive små risikoer og underdrive de store. Vi er mye reddere for det vi ikke kjenner (et nytt virus), enn det vi er vant til (influensaepidemier). I tillegg preges vi av hva vi nylig har opplevd, og hva som til enhver tid preger nyhetsbildet. Etter terrorangrepet 11. september 2001 var for eksempel mange (naturlig nok) redde for å fly og kjørte lange strekninger med bil i stedet. I løpet av året som fulgte, døde omkring 1500 flere amerikanere i trafikken enn vanlig (7.).

\section{«Når en epidemi er i emning, skal helsemyndighetene vare forberedt på det verste. Samtidig skal befolkningen få nøktern og oppdatert informasjon"}

Ordlegging har også betydning: En klassisk studie fra 1981 demonstrerte at valg av behandlingsalternativer for en tenkt egen kreftsykdom ble påvirket av om utfallet ble presentert som sannsynligheten for å overleve versus sannsynligheten for å d $\emptyset$ (ㅁ). Selv om tallene var de samme. Kanskje de mest bekymrede av oss burde få informasjon om sannsynligheten for å overleve en infeksjon med SARS-CoV-2 (svært høy for mange), enn sannsynligheten for å dø?

Hvordan vi reagerer på informasjon om en mulig epidemi, avhenger nemlig også av en rekke individuelle faktorer. Vi har ulik oppfattelse av egen sårbarhet for sykdom, er ulikt disponert for frykt og har ulik toleranse for å tåle usikkerhet $(9, \underline{10})$. Dermed vil en situasjon som denne måtte skape en viss grad av overreaksjon. Hvis ikke når man ikke frem med informasjon om viktige tiltak til de som kanskje er for ubekymret, men som også må mobiliseres til en smitteverndugnad. Det ideelle hadde antakelig vært en form for persontilpasset medisin: Enhver får informasjon ut fra alder, kjønn, sykehistorie og sårbarhet for engstelse. Det er imidlertid ikke mulig i et moderne informasjonssamfunn der alle har, og skal ha, tilgang til alt.

En av de største truslene mot å kunne håndtere en epidemi er at helsevesenet overbelastes av de friske, men bekymrede (9.). Derfor er det etablert telefonlinjer der enkeltpersoner kan henvende seg for å få persontilpasset informasjon. I tillegg er det gledelig at tabloidpressen ser ut til å ha dempet bruken av varseltrekanter og helsider med helsepersonell i fullt verneutstyr. Slike virkemidler varsler nemlig ikke om ulv, men brøler om en rasende flokk av dem.

\section{LITTERATUR}

1. Ohio bridal shop visited by Ebola patient closing down. Reuters 8.1.2015. https://www.reuters.com/article/usa-ohio-ebola/ohio-bridal-shop-visited-by-ebola-patient-closingdown-idUSL1NoUN1KY20150108 Lest 2.3.2020.

2. Report of the WHO-China Joint Mission on Coronavirus Disease 2019 (COVID-19). https://www.who.int/docs/default-source/coronaviruse/who-china-joint-mission-on-covid-19-finalreport.pdf Lest 2.3.2020.

3. COVID-19: fighting panic with information. Lancet 2020; 395: 537. [PubMed][CrossRef] 
4. Rangnes HK, Zondag MHW, Rørslett et al. Advarer mot hamstring av mat. NRK 28.2.2020. https://www.nrk.no/vestfoldogtelemark/hamstrer-mat-i-korona-frykt-1.14921952 Lest 3.2.2020.

5. Smith RD. Responding to global infectious disease outbreaks: lessons from SARS on the role of risk perception, communication and management. Soc Sci Med 2006; 63:3113-23. [PubMed][CrossRef]

6. Teigen KH. Terningen er rund. Oslo: Cappelen Damm Akademisk, 2017.

7. Gigerenzer G. Out of the frying pan into the fire: behavioral reactions to terrorist attacks. Risk Anal 2006; 26: 347-51. [PubMed][CrossRef]

8. McNeil BJ, Pauker SG, Sox HC et al. On the elicitation of preferences for alternative therapies. N Engl J Med 1982;306:1259-62. [PubMed][CrossRef]

9. Asmundson GJG, Taylor S. Coronaphobia: Fear and the 2019-nCoV outbreak. J Anxiety Disord 2020; 70:102196. [PubMed][CrossRef]

10. Perrin PC, McCabe OL, Everly GS et al. Preparing for an influenza pandemic: mental health considerations. Prehosp Disaster Med 2009; 24: 223-30. [PubMed][CrossRef]

Publisert: 6. mars 2020. Tidsskr Nor Legeforen. DOI: 10.4045/tidsskr.20.019o

(C) Tidsskrift for Den norske legeforening 2023. Lastet ned fra tidsskriftet.no 26. april 2023. 